\title{
Co-occurring cryptic species pose challenges for conservation: a case study of the African dwarf crocodile (Osteolaemus spp.) in Cameroon
}

\author{
NiCOLE L. SMOLENSKY
}

\begin{abstract}
The conservation status of threatened taxa may be obfuscated by the detection of cryptic species complexes, in both vertebrate and invertebrate species. African dwarf crocodiles (Osteolaemus spp.) are hunted throughout their range but their conservation status is unknown. Few population assessments have been carried out and there has been a taxonomic revision of the number of species in the genus. The similar morphologies of Osteolaemus tetraspis and Osteolaemus osborni pose a challenge for conservation in Cameroon, where they are still managed as a single species. Nocturnal spotlight surveys were conducted in three regions during August-November 2010 and December 2011-February 2012 to provide population assessments of $O$. tetraspis and O. osborni and raise awareness of the two species in Cameroon. The mean encounter rates of O. tetraspis and O. osborni were $1.02 \pm$ SD 1.34 (65 individuals in 39 surveys) and $0.61 \pm \mathrm{SD} 0.38$ (three in four surveys) crocodiles per $\mathrm{km}$, respectively. The $O$. tetraspis population comprised juveniles predominantly and had a male-biased sex ratio. The few O. osborni detected comprised both adults and juveniles. Both species are threatened in Cameroon, based on low encounter rates, young population structures and the threats of habitat loss and hunting pressure. This study provides distribution maps and serves as a baseline to quantify population trends and inform conservation strategies.
\end{abstract}

Keywords Cameroon, crocodile, cryptic species, hunting pressure, Osteolaemus, population status

\section{Introduction}

\footnotetext{
7 he conservation status of a species is determined by its distribution, population size, demographic structure, and associated threats (IUCN, 2012a). This information is also used as a basis for management and conservation strategies (Meffe \& Carroll, 1997; Mills, 2007). However, these data are lacking for $24 \%$ of species categorized on the IUCN Red List (IUCN, 2012b). Molecular evidence indicates

Nicole L. Smolensky Department of Wildlife and Fisheries Sciences, 210 Nagle Hall, Texas A\&M University, College Station, Texas 77843-2258, USA

E-mailnsmo@tamu.edu

Received 3 January 2014. Revision requested 9 April 2014.

Accepted 8 August 2014. First published online 18 December 2014.
}

that several species on the Red List may actually be complexes of cryptic species (Pfenninger \& Schwenk, 2007; Murray et al., 2008). This taxonomic challenge can have significant ramifications for our understanding of the distribution, population status, management and legislative protection of these threatened cryptic species (Bell et al., 1998; Mace, 2004; Sattler et al., 2007). For example, two species of woolly spider monkeys, the Endangered Brachyteles arachnoides and the Critically Endangered Brachyteles hypoxanthus, were previously thought to be a single species. Captive-breeding programmes intended to augment B. arachnoides populations included hybrids of the two species, which, if introduced into the small population of B. hypoxanthus could have resulted in its genetic extinction (Brito, 2004). The status and management of threatened taxa must be assessed on an ongoing basis as taxonomies are refined.

The African dwarf crocodiles (Osteolaemus spp.) provide an example of the heuristic approach needed to manage and conserve biodiversity effectively as species' taxonomies change. Osteolaemus was formerly a monotypic genus containing two subspecies, Osteolaemus tetraspis tetraspis and Osteolaemus tetraspis osborni, which were widely distributed in equatorial lowland rainforests of West and Central Africa. They were managed as a single species, listed in Appendix I of CITES (CITES, 2014) and categorized as Vulnerable on the IUCN Red List (IUCN, 2012b) because of the threats of habitat loss and hunting pressure (Eaton, 2010). However, studies have shown the genus comprises three species: Osteolaemus sp. nov., O. tetraspis and O. osborni (Eaton et al., 2009; Franke et al., 2013; Shirley et al., 2014; Smolensky et al., 2014). Efforts are underway to characterize the distribution and population status and develop captive-breeding programmes for all three species (Eaton et al., 2009; Eaton, 2010; Franke et al., 2013; Shirley et al., 2014; Smolensky et al., 2014; Schmidt et al., in press).

Osteolaemus sp. nov. occurs in the upper Guinean rainforests (Fig. 1). It has been extirpated from the extreme western part of its range. The southern coasts of Ghana and Côte d'Ivoire may be the last remaining strongholds for this species (Waitkuwait, 1989; Kofron, 1992; Shirley et al., 2009; Eaton, 2010). Osteolaemus tetraspis and O. osborni occur in the lower Guinean and Congo rainforests, respectively (Fig. 1). Population assessments of O. tetraspis and O. osbor$n i$ are few, mostly outdated, and indicate low densities where they are exploited for bushmeat (Riley \& Huchzermeyer, 


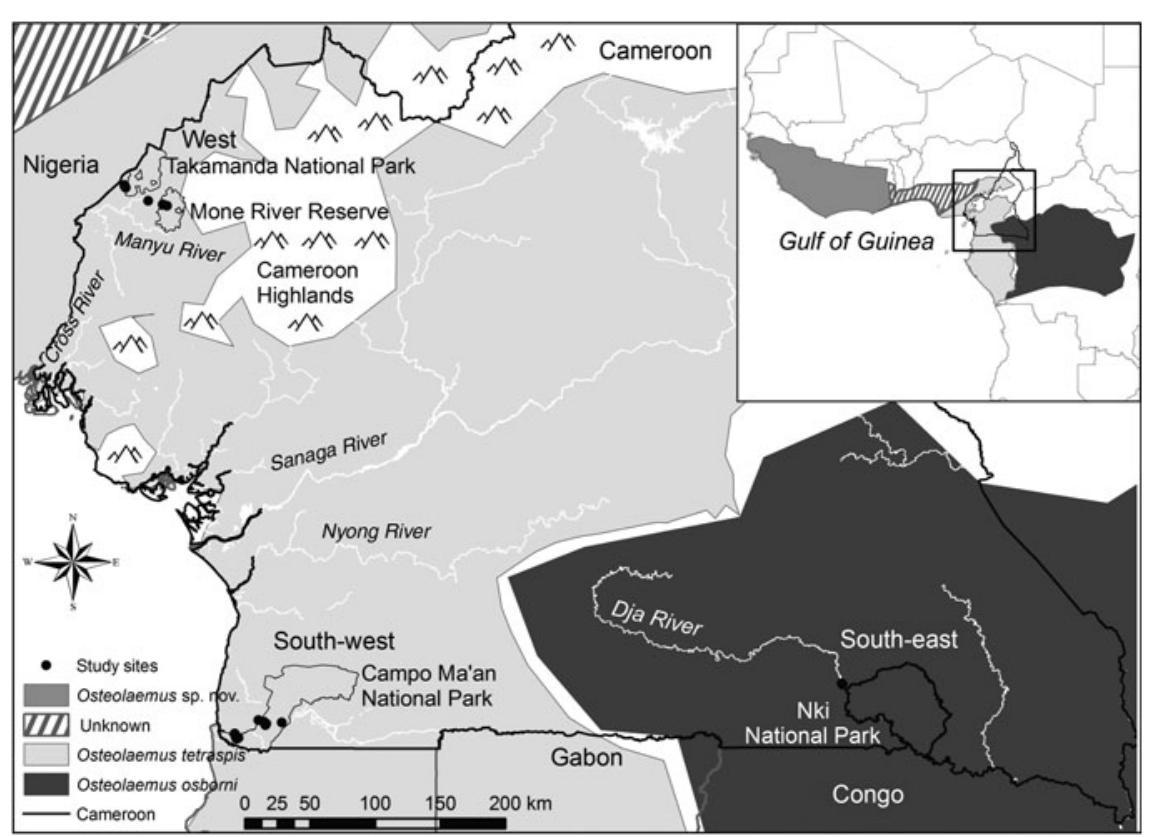

FIG. 1 The West, South-west and South-east study sites in the lowland Congo-Guinean rainforest in Cameroon, where surveys were conducted for the African dwarf crocodiles Osteolaemus tetraspis and Osteolaemus osborni. The rectangle on the inset shows the location of the main map in Africa.
1999; Wild, 2000; Eaton, 2006, 2010). In light of these taxonomic revisions and current threats to the species, population assessments are needed to update their conservation status and inform appropriate management to conserve their evolutionary diversity.

The co-occurrence of cryptic taxa further complicates conservation status assessments of species. Smolensky et al. (2014) confirmed the co-occurrence of O. tetraspis and O. osborni in Cameroon. Osteolaemus tetraspis is widely distributed there but is threatened by hunting and deforestation (Wild, 2000; Gonwouo \& LeBreton, 2010). These latest assessments were conducted during 1990-2004 and were presence/absence surveys, except at one site where population density surveys were conducted (Wild, 2000). There have been no population density assessments of O. osborni.

Here I provide information on the population ecology of O. tetraspis and O. osborni in Cameroon to facilitate independent conservation of these species. I present the first population assessments of O. osborni and O. tetraspis, a reassessment of the western population of O. tetraspis, and distribution maps for both species.

\section{Study area}

During 18 August-21 November 2010 and 17 December 2011-16 February 2012 I conducted population surveys in three study regions (West, South-west and South-east) in the lowland Congo-Guinean rainforest in Cameroon (Fig. 1). The West study region was where Wild (2000) conducted an assessment of O. tetraspis in 1998, facilitating a temporal comparison of population estimates with this study, and an assessment of the population trend.
I conducted surveys within the Mone River Reserve, on the southern border of the Takamanda National Park, and near the villages of Okpambe and Ebinsi, located between the Reserve and the Park (Fig. 1). The South-west region provided an additional site for a spatial comparison of $O$. tetraspis populations, facilitating assessment of the status of the species at a broad scale. In this region surveys were conducted during 2010-2012 in the Campo Ma'an National Park, specifically in the sections known as Ile Dipikar and Corridor. The Congo Basin in the South-east is the only region known to harbour O. osborni, and was chosen to provide the first assessments for this species in Cameroon (Smolensky et al., 2014).

Study sites in each region were selected based on road access, proximity to a protected area, and anecdotal evidence of Osteolaemus presence. All sites were at low elevation $(<500 \mathrm{~m})$, with dense canopy cover and gallery forest vegetation. Streams in the West and South-west were 1-10 m wide and had clear, slow-flowing water of depth $<0.25^{-1}$ $\mathrm{m}$ but typically $<0.5 \mathrm{~m}$. The Dja River, in the South-east study region, is a major tributary of the Congo Basin, with turbid waters, maximum width $120 \mathrm{~m}$, and mean annual discharge $450-500 \mathrm{~m}^{3} \mathrm{~s}^{-1}$ (Seyler et al., 1993).

\section{Methods}

Nocturnal spotlight surveys were conducted to obtain a census of crocodile populations (Chabreck, 1966). The number of surveys was reduced at sites where initial surveys yielded few encounters. Surveys entailed wading, walking or canoeing along the edges of the Dja River. I surveyed the edges of the river, where flow was reduced and canopy cover was dense. 
TABLE 1 Mean encounter rates for the African dwarf crocodiles Osteolaemus tetraspis in the South-west and West and Osteolaemus osborni in the South-east study sites of the lowland Congo-Guinean rainforest in Cameroon (Fig. 1).

\begin{tabular}{|c|c|c|c|c|c|c|}
\hline Study region & Site & No. of surveys & Survey distance $(\mathrm{km})$ & No. detected & No. captured & $\begin{array}{l}\text { Mean encounter } \\
\text { rate } \pm S D \text { (indi- } \\
\text { viduals per km) }\end{array}$ \\
\hline \multicolumn{7}{|l|}{ Osteolaemus tetraspis } \\
\hline \multirow[t]{2}{*}{ South-west } & Ile Dipikar & 16 & 40.54 & 35 & 25 & $1.01 \pm 0.98$ \\
\hline & Corridor & 11 & 26.20 & 10 & 7 & $0.48 \pm 0.58$ \\
\hline Total & & 27 & 66.70 & 45 & 32 & $0.79 \pm 0.88$ \\
\hline \multirow[t]{5}{*}{ West } & Mone river & 5 & 3.38 & 9 & 6 & $2.16 \pm 2.75$ \\
\hline & Okpambe & 2 & 3.70 & 2 & 1 & $0.56 \pm 0.11$ \\
\hline & Ebinsi & 1 & 1.30 & 0 & 0 & 0.00 \\
\hline & Kekukesem & 3 & 3.91 & 9 & 5 & $2.17 \pm 0.84$ \\
\hline & Takamanda* & 1 & 1.70 & 0 & 0 & 0.00 \\
\hline Total & & 12 & 13.99 & 20 & 12 & $1.54 \pm 2.04$ \\
\hline Total for both regions & & 39 & 80.69 & 65 & 44 & $1.02 \pm 1.34$ \\
\hline \multicolumn{7}{|l|}{ Osteolaemus osborni } \\
\hline South-east & Nki & 4 & 24.71 & 13 & 3 & $0.61 \pm 0.38$ \\
\hline
\end{tabular}

${ }^{*}$ In the Takamanda National Park (c.f. Wild, 2000)

Each survey began 2 hours after dusk and ended 2-4 hours before dawn. Each stream was searched during 1-3 nights, covering different sections of the stream each night. Start and end points were recorded using a global positioning system, to map the location and length of each survey. A white LED headlamp (20o lumens) was used to detect crocodiles, which typically were solitary. The waters were clear and shallow, which facilitated detection of submerged crocodiles. I attempted to capture all crocodiles to obtain morphometric measurements and tissue samples for species identification via genetic analyses. Smaller individuals were grabbed by hand and larger individuals were captured using a snare-pole (Hutton et al., 1987). For each crocodile, I recorded its location, snout-vent length, total length and sex. Crocodiles were given unique identifying marks by removal of caudal scutes (Webb \& Messel, 1977), and released at the site of capture.

Sex was determined for individuals of total length $>40$ $\mathrm{cm}$. Crocodiles were categorized according to life-stage, based on studies of captive and wild Osteolaemus populations (Beck, 1978; Teichner, 1978; Tryon, 1980; Eaton, 2009): hatchlings $(<24 \mathrm{~cm})$, juveniles $(24-99 \mathrm{~cm})$ and adults $(>100 \mathrm{~cm})$. Crocodiles that evaded capture were not categorized.

Encounter rates and population structure were used to assess the population status of O. tetraspis and of O. osborni. Encounter rates were recorded as the number of crocodiles detected per $\mathrm{km}$ of river habitat, and served as relative population density indices. Population structure was the relative proportions of captured individuals in each size category. Encounter rates and population structures in the three study regions were compared using Kruskal-Wallis and Fisher's exact tests, respectively. For the South-west, where surveys were conducted for 2 years, a Wilcoxon signed-rank test was used to compare encounter rates and population structure between years.

\section{Results}

Forty-three nocturnal spotlight surveys were conducted (27 in the South-west, 12 in the West and four in the South-east), covering a total of $105.4 \mathrm{~km}$ of stream and river habitat across the three study regions. Sixty-five O. tetraspis and 13 O. osborni were encountered. Crocodiles were detected in all regions and at $75 \%$ of the eight survey sites (Table 1 ), although in general the encounter rate at individual sites was low (Table 1). The mean encounter rates for O. tetraspis and O. osborni were $1.02 \pm \mathrm{SD} 1.34$ (65 individuals in 39 surveys) and $0.61 \pm \mathrm{SD} 0.3834$ crocodiles per $\mathrm{km}$ (three in four surveys), respectively. Encounter rates did not differ among regions $(H=0.06, \mathrm{P}=0.80)$ or among sites $(H=6.25$, $\mathrm{P}=0.51)$.

The mean encounter rate of $O$. tetraspis populations from Takamanda and Kekukesem, sites previously surveyed in 1998 (Wild, 2000), declined from three to 1.01 crocodiles per $\mathrm{km}$. Encounter rates in the South-west also declined, from $1.31 \pm$ SD $1.13(n=11$ surveys $)$ in 2010 to $0.44 \pm$ SD 0.46 crocodiles per $\mathrm{km}(\mathrm{n}=16)$ in 2012 but the decrease was not significant $(\mathrm{W}=-1.94, \mathrm{P}=0.053)$. No crocodiles marked in 2010 were re-captured in 2012.

O. tetraspis populations were composed predominantly of juveniles (Fig. 2). In the South-west juveniles comprised $75 \%(n=24)$ of the population, and adults $25 \%(n=8)$. No hatchlings were detected although $22 \%$ of the juveniles had recently entered this size category and were $30-35 \mathrm{~cm}$ in total length (Fig. 2). The population structure was unchanged between 2010 and 2012. In the West, juveniles comprised $83.3 \%(\mathrm{n}=10)$ of the population, and adults $16.7 \%$ 


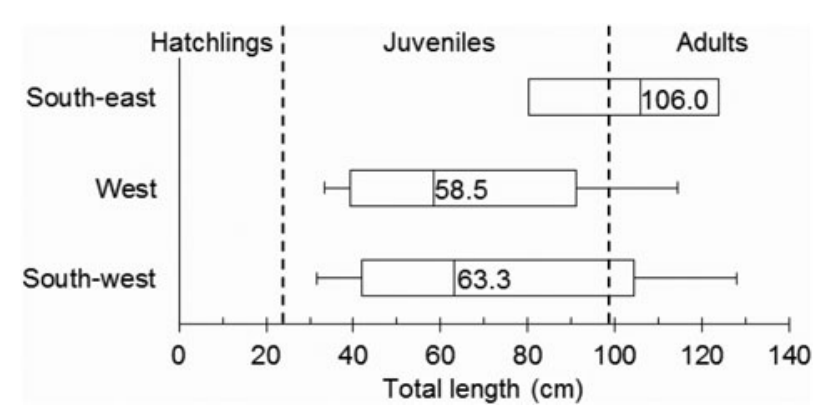

FIg. 2 Population structure of O. tetraspis at study sites in the west $(n=12)$ and south-west $(n=32)$ of the lowland CongoGuinean rainforest in Cameroon (Fig. 1), and of O. osborni in the south-east $(\mathrm{n}=3)$. Dashed vertical lines represent the divisions between hatchlings ( $<24 \mathrm{~cm}$ total length), juveniles $(<100 \mathrm{~cm}$ total length) and adults, based on Beck (1978),

Teichner (1978), Tryon (1980) and Eaton (2009). The numbers to the right of the median are mean encounter rates, and error bars represent minimum and maximum sizes of captured crocodiles.

$(\mathrm{n}=2)$. Two of the juveniles were $30-35 \mathrm{~cm}$ in total length. There was no significant difference in the population structure between regions $(\mathrm{F}=2.89, \mathrm{P}=0.19)$. The sex ratio was male-biased $(1.75: 1, \mathrm{n}=22)$ in the South-west and femalebiased in the West $(0.67: 1, \mathrm{n}=5)$ and South-east $(1: 2$, $\mathrm{n}=3$ ).

Two adult and one juvenile O. osborni were captured in the South-east study region. O. osborni detected but not captured also fell within these size categories.

\section{Discussion}

These results provide information on the population status of $O$. tetraspis throughout its range in Cameroon, and the first estimate of O. osborni population densities in Cameroon. Encounter rates of both species were low. They were comparable to exploited populations of these species in similar habitats in the Republic of the Congo, and 4.5 times lower than encounter rates of unexploited O. tetraspis populations in Gabon (Eaton, 2009). Both species are hunted throughout Cameroon but the intensity of hunting pressure is unknown (Wild, 2000). The low encounter rates of both species, and the juvenile-biased population structure of $O$. tetraspis, may be indicative of unsustainable exploitation (Webb et al., 2000). Additional factors not associated with hunting that may have influenced observed encounter rates are discussed below. The wide distribution of $O$. tetraspis throughout Cameroon may be critical for its persistence in the country (Smolensky et al., 2014). Osteolaemus osborni has a much narrower distribution and the low encounter rate implies a tenuous status in Cameroon.

Encounter rates of $O$. tetraspis were similar across its range. In many of the surveys in the South-west and West one or no individuals were encountered in $2.5 \mathrm{~km}$ of river habitat, with encounter rates of two or more crocodiles per $\mathrm{km}$ being more common in the West. The habitats were similar in their physical and vegetation characteristics but differed in levels of anthropogenic disturbance. The sites adjacent to or in the protected areas of the West were remote, with lower human population densities and fewer logging concessions and roads in the surrounding area compared to sites in the South-west. Sites far from protected areas (e.g. Ebinsi) had even lower encounter rates, which may be attributable to degraded habitats, lack of enforcement of hunting regulations, and fishing methods involving the use of poisonous organo-chloride insecticides (Gonwouo \& LeBreton, 2010). Cameroon's human population density, infrastructure development and agriculture sector have doubled since 2000 (de Wasseige, 2012; World Bank, 2014). Thus the decline in encounter rates, from three (Wild 2000) to 1.01 crocodiles per $\mathrm{km}$ in the West, may be a result of increased exploitation. Alternatively, lower encounter rates may be associated with edge effects around protected areas (Woodroffe \& Ginsberg, 1998), as my surveys were conducted on the edge of the Takamanda National Park whereas those of Wild (2000) were conducted in the interior of the Park.

In the South-west encounter rates also decreased during 2010-2012 although not significantly. Although it may take several years to detect changes in population structures of crocodiles (Webb et al., 200o), the observed differences may reflect a change in activity rates. In 2010 surveys were conducted at the end of the rainy season, which probably coincides with the end of the mating season and the beginning of the nesting period (Waitkuwait, 1989; Kofron \& Steiner, 1994; Eaton, 2009), whereas in 2012 surveys were conducted at the end of the dry season, when the availability of aquatic prey is low, and therefore more individuals may be inactive, remaining in burrows until the onset of the rainy season (Brummett \& Teugels, 2004).

The lowest encounter rates were recorded for the O. osborni population, which may be attributed to the combined threats of hunting pressure and drowning in gillnets. The turbidity of the waters of the Dja River, compared with the clear-water streams surveyed for $O$. tetraspis, may also have resulted in lower detection rates (Bayliss, 1987; Hutton \& Woolhouse, 1989). It is unlikely that low encounter rates were a result of poor habitat, as Osteolaemus species use a variety of aquatic habitats, including rivers (Eaton, 2009).

Population structure may be influenced by the type of aquatic habitat. Although few O. osborni individuals were caught they were adults and large juveniles detected at the edges of a large river, whereas small and large $O$. tetraspis were detected in small tributaries in the West and South-west. These findings may be a result of ontogenetic shifts in habitat use, whereby small crocodiles are less common in larger rivers because of the higher predation risk (Subalusky et al., 2009). In the South-west and West the 
population structure was skewed towards juveniles, a situation that is often attributed to size-selective hunting pressure (Montague, 1983; Webb et al., 2000). However, the population structures were similar to those of populations in Gabon not subject to hunting pressure (Eaton, 2009). Thus, proportionally higher numbers of juveniles in the population may be typical of $O$. tetraspis populations surveyed during the dry season. Females are nesting during this period and may be located several metres away from water, which may account for the male-biased sex ratio observed in the South-west population (Waitkuwait, 1989).

Cameroon provides an important case study for Osteolaemus species and cryptic taxa in general, as it is one of two countries known to harbour two Osteolaemus species, the other being the Republic of the Congo (Eaton, 2010; Smolensky et al., 2014). Separate population assessments were conducted and distribution maps provided to raise awareness of the two cryptic species in Cameroon, providing a baseline to determine the stability of the density and structure of the country's O. tetraspis and O. osborni populations. The low encounter rates of both species, the young population structure of $O$. tetraspis, and the increasing threats of habitat loss and hunting pressure indicate that both species are threatened in Cameroon, and both merit categorization as Vulnerable there. The conservation status of O. osborni may worsen if national and international policy and management are not revised to protect this unique species.

The similar morphologies of O. tetraspis and O. osborni pose a hybridization risk for both in situ and ex situ management programmes. Hybridization has been detected in captive-breeding programmes in European zoos, and efforts are underway to mitigate this and curtail translocations or reintroductions of hybrids into wild populations (Franke et al., 2013; Schmidt et al., in press). In Cameroon, management authorities and conservation organizations confiscate live crocodiles from the bushmeat trade and release them back into the wild but not necessarily into their original populations (NLS, pers. obs.), creating the potential for hybridization. The distribution maps provided here and elsewhere (Smolensky et al., 2014) should mitigate some of these hybridization risks. I recommend that confiscated crocodiles be released back to their original populations. Regional and national reports of these findings are being distributed to governmental ministries and non-governmental agencies. Plans for continued monitoring are underway, in addition to further delineation of O. tetraspis and O. osborni distributions, particularly where contact zones may occur.

As species' taxonomies are revised, population assessments and reassessments are important in conserving their evolutionary diversity. Continued monitoring of $O$. tetraspis and O. osborni populations would elucidate whether the observed juvenile-biased population structures are typical of Osteolaemus populations or are indicators of overexploitation. Further studies on reproductive phenology and seasonal activity patterns would facilitate our understanding of the spatial and temporal variability of O. tetraspis populations. Although crocodile ranching and farming has been a successful conservation strategy for exploited crocodile species (Crocodile Specialist Group, 2014), preliminary assessments indicate this would not be an economically viable strategy for Osteolaemus species in Cameroon (Behra, 1993). My results suggest that protected areas are important havens for populations of $O$. tetraspis and that they should be extensive, with enforcement of wildlife laws and limited access to their interiors. Sustainable livelihood opportunities must be created for local communities to offset the costs of reduced hunting.

\section{Acknowledgements}

Funding for this research was provided by the Alfred P. Sloan Foundation, the Crocodile Specialist Group Student Research Assistance Scheme, the LT Jordan MSC International Awareness Fellowship, the Rufford Foundation, and Texas A\&M University Diversity Fellowship. Drs Chuyong, Fotso, Hanson, Legrand, and Nchanji, and Messrs Foguekem, Mulema, Ikfuengi, and Kilanga assisted with permits from the Ministries of Scientific Research and Forests and Wildlife. I thank local councilmen, chiefs, conservators, and regional delegates for granting access to the study regions. Logistical support was provided by local hunters and $\mathrm{Mr}$ Fouda and family. Drs Fitzgerald, Hibbitts and Ryberg, and two anonymous reviewers, provided comments that improved this article. This publication is number 1476 of the Biodiversity Research and Teaching Collections and was approved by Texas A\&M University: Animal Use Protocol2010-123.

\section{References}

BAYLISS, P. (1987) Survey methods and monitoring within crocodile management programmes. In Wildlife Management: Crocodiles and Alligators (eds G. Webb, C. Manolis \& P. Whitehead), pp. 157-175. Surrey Beatty \& Sons, Chipping Norton, Australia.

Beск, C. (1978) Breeding the West African dwarf crocodile Osteolaemus tetraspis tetraspis at Memphis Zoo. International Zoo Yearbook, 18, 89-91.

Behra, O. (1993) Area reports: Cameroon FAO Crocodile Management Project. Crocodile Specialist Group Newsletter, 12, 16. Http://www.iucncsg.org/365_docs/attachments/protarea/CSG\% 20-24e58088.pdf [accessed 2 September 2014].

Bell, B.D., Daugherty, C.H. \& Hay, J.M. (1998) Leiopelma pakeka, n. sp. (Anura: Leiopelmatidae), a cryptic species of frog from Maud Island, New Zealand, and a reassessment of the conservation status of L. hamiltoni from Stephens Island. Journal of the Royal Society of New Zealand, 28, 39-54.

BRITO, D. (2004) Lack of adequate taxonomic knowledge may hinder endemic mammal conservation in the Brazilian Atlantic Forest. Biodiversity and Conservation, 13, 2135-2144. 
Brummett, R. \& Teugels, G. (2004) Rivers of the lower Guinean rainforest: biogeography and sustainable exploitation. In Proceedings of the Second International Symposium on the Management of Large Rivers for Fisheries, pp. 149-172.

Chabreck, R.H. (1966) Methods of determining the size and composition of alligator populations in Louisiana. Proceedings of the Annual Conference of the South-eastern Association of Fish and Wildlife Agencies, 20, 105-112.

CITES (2014) Convention on International Trade in Endangered Species of Wild Fauna and Flora. Appendices I, II and III. Http:// cites.org/eng/app/appendices.php [accessed 1 September 2014].

Crocodile Specialist Group (2014) Sustainable Utilization. Http:// www.iucncsg.org/pages/Sustainable-Utilization.html [accessed 9 July 2014].

DE WAsseige, C. (coordinator) (2012) The Forests of the Congo Basin -State of the Forest 2010. Publications Office of the European Union, Luxembourg, Luxembourg.

EATON, M.J. (2006) Ecology, conservation and management of the Central African dwarf crocodile (Osteolaemus tetraspis). A progress report. In Proceedings of the 18th Working Meeting of the Species Survival Commission of the IUCN-SSC Crocodile Specialist Group, pp. 84-95. IUCN, Gland, Switzerland.

EATON, M.J. (2009) Systematics, population structure and demography of the African dwarf crocodile (Osteolaemus spp.): a perspective from multiple scales. $\mathrm{PhD}$ thesis. University of Colorado, Boulder, Colorado.

Eaton, M.J. (2010) Dwarf crocodile Osteolaemus tetraspis. In Crocodiles: Status Survey and Conservation Action Plan, 3rd edition (eds S.C. Manolis \& C. Stevenson), pp. 127-132. Crocodile Specialist Group, Darwin, Australia.

Eaton, M.J., Martin, A., Thorbjarnarson, J. \& Amato, G. (2009) Species-level diversification of African dwarf crocodiles (Genus Osteolaemus): a geographic and phylogenetic perspective. Molecular Phylogenetics and Evolution, 50, 496-506.

Franke, F.A., Schmidt, F., Borgwardt, C., Bernhard, D., Bleidorn, C., Engelmann, W.-E. \& Schlegel, M. (2013) Genetic differentiation of the African dwarf crocodile Osteolaemus tetraspis Cope, 1861 (Crocodylia: Crocodylidae) and consequences for European zoos. Organisms Diversity \& Evolution, 13, 255-266.

Gonwouo, L. \& LeBreton, M. (2010) An overview of the distribution and present status of crocodiles in Cameroon. In Proceedings of 2nd Regional Meeting of the Crocodile Specialist Group on the Promotion and Conservation of Crocodilians in West Africa, pp. 176-183. IUCN, Nazinga, Burkina Faso.

Hutton, J., Loveridge, J. \& Blake, D. (1987) Capture methods for the Nile crocodile in Zimbabwe. In Wildlife Management: Crocodiles and Alligators (eds G. Webb, S. Manolis \& P. Whitehead), pp. 243247. Surrey Beatty and Sons, Chipping Norton, Australia.

Hutton, J. \& Woolhouse, M. (1989) Mark-recapture to assess factors affecting the proportion of a Nile crocodile population seen during spotlight counts at Ngezi, Zimbabwe, and the use of spotlight counts to monitor crocodile abundance. Journal of Applied Ecology, 26, 381-395.

IUCN (2012a) IUCN Red List Categories and Criteria (version 3.1). IUCN, Gland, Switzerland and Cambridge, UK. Http://jr. iucnredlist.org/documents/redlist_cats_crit_en.pdf [accessed 2 September 2014].

IUCN (2012b) IUCN Red List of Threatened Species v. 2012.2. Http:// www.iucnredlist.org [accessed 6 June 2013].

Kofron, C.P. (1992) Status and habitats of the three African crocodiles in Liberia. Journal of Tropical Ecology, 8, 265-273.

Kofron, C.P. \& Steiner, C. (1994) Observations of the African dwarf crocodile, Osteolaemus tetraspis. Copeia, 2, 533-535.
MACE, G.M. (2004) The role of taxonomy in species conservation. Philosophical Transactions of the Royal Society B: Biological Sciences, 359, 711-719.

Meffe, G.K. \& Carroll, C.R. (1997) Principles of Conservation Biology. Sinauer Associates, Sunderland, USA.

Mills, L.S. (2007) Conservation of Wildlife Populations: Demography, Genetics, and Management. Blackwell Publishing, Malden, USA.

Montague, J.J. (1983) Influence of water level, hunting pressure and habitat type on crocodile abundance in the Fly River drainage, Papua New Guinea. Biological Conservation, 26, 309-339.

Murray, T.E., Fitzpatrick, U., Brown, M.J. \& Paxton, R.J. (2008) Cryptic species diversity in a widespread bumble bee complex revealed using mitochondrial DNA RFLPs. Conservation Genetics, 9, 653-666.

Pfenninger, M. \& Schwenk, K. (2007) Cryptic animal species are homogeneously distributed among taxa and biogeographical regions. BMC Evolutionary Biology, 7, 121-126.

Riley, J. \& Huchzermeyer, F.W. (1999) African dwarf crocodiles in the Likouala Swamp Forests of the Congo Basin: habitat, density, and nesting. Copeia, 1999, 313-320.

Sattler, T., Bontadina, F., Hirzel, A.H. \& Arlettaz, R. (2007) Ecological niche modelling of two cryptic bat species calls for a reassessment of their conservation status. Journal of Applied Ecology, 44, 1188-1199.

Schmidt, F., Franke, F.A., Shirley, M.H., Vliet, K.A. \& Villanova, V.L. (In press). The importance of genetic research in zoo breeding programmes for threatened species: the African dwarf crocodiles (Genus Osteolaemus) as a case study. International Zoo Yearbook.

Seyler, P., Olivry, J. \& Nkamdjou, L. (1993) Hydrogeochemistry of the Ngoko River, Cameroon: chemical balances in a rainforest equatorial basin. In Hydrology of Warm Humid Regions, pp. 87-105. IAHS Press, Wallingford, UK.

Shirley, M.H., Oduro, W. \& Beibro, H.Y. (2009) Conservation status of crocodiles in Ghana and Côte-d'Ivoire, West Africa. Oryx, 43, $136-145$.

Shirley, M.H., Villanova, V., Vliet, K.A. \& Austin, J.D. (2014) Genetic barcoding facilitates captive management of three cryptic African crocodile species complexes. Animal Conservation. Http:// www.dx.doi.org/10.1111/acv.12176 [accessed 5 December 2014].

Shirley, M.H., Vliet, K.A., Carr, A.N. \& Austin, J.D. (2014) Rigorous approaches to species delimitation have significant implications for African crocodilian systematics and conservation. Proceedings of the Royal Society B: Biological Sciences, 281, 20132483.

Smolensky, N.L., Hurtado, L.A. \& Fitzgerald, L.A. (2014) DNA barcoding of Cameroon samples enhances our knowledge on the distributional limits of putative species of Osteolaemus (African dwarf crocodiles). Conservation Genetics. Http://dx.doi.org/10.1007/ s10592-014-0639-3 [accessed 3 September 2014].

Subalusky, A.L., Fitzgerald, L.A. \& Smith, L.L. (2009) Ontogenetic niche shifts in the American alligator establish functional connectivity between aquatic systems. Biological Conservation, 142, 1507-1514.

Teichner, O. (1978) Breeding the West African dwarf crocodile, Osteolaemus tetraspis tetraspis, at Metro Toronto Zoo. International Zoo Yearbook, 18, 88-89.

TRYON, B.W. (1980) Observations on reproduction in the West African dwarf crocodile with a description of parental behavior. In Reproductive Biology and Diseases of Captive Reptiles (eds J.B. Murphy \& J.T. Collins), 167-185. Society for the Study of Amphibians and Reptiles, Oxford, USA.

Waitkuwait, W.E. (1989) Present knowledge on the West African slender-snouted crocodile, Crocodylus cataphractus Cuvier 1824 and the West African dwarf crocodile, Osteolaemus tetraspis, Cope 
1861. In Crocodiles: Their Ecology, Management, and Conservation IUCN Publication New Series, pp. 260-275. IUCN, Gland, Switzerland.

Webb, G.J.W., Britton, A., Manolis, S., Ottley, B. \& Stirrat, S. (2000) The recovery of Crocodylus porosus in the Northern Territory of Australia: 1971-1998. In Proceedings of the 15th Working Meeting of the Crocodile Specialist Group, pp. 195-234. IUCN, Gland, Switzerland.

Weвв, G.J.W. \& Messel, H. (1977) Crocodile capture techniques. The Journal of Wildlife Management, 41, 572-575.

WILD, C. (2000) Report on the status of crocodilians in the Cameroon Forest Zone. In Proceedings of the 15th Working Meeting of the Crocodile Specialist Group, pp. 539-543. IUCN, Gland, Switzerland.

Woodroffe, R. \& Ginsberg, J.R. (1998) Edge effects and the extinction of populations inside protected areas. Science, 280, 21262128 .
WORLD BANK (2014) World Development Indicators. Https://www. google.com/publicdata/explore?ds=d5bncppjof8f9_

\&met_y=sp_pop_grow\&hl=en\&dl=en\#!strail=false\&bcs= $\mathrm{d} \&$ nselm $=\mathrm{h} \& \mathrm{rdim}=$ region\&idim $=$ country: $\mathrm{CMR} \&$ ifdim $=$ region \&tstart $=963032400000 \&$ tend $=1183870800000 \& \mathrm{hl}=$ en_US\&dl=en\&ind=false [accessed 7 July 2014].

\section{Biographical sketch}

Nicole SMOLENSKY's research interests lie in the population ecology and conservation of reptiles. She uses a combination of field methods and molecular and biochemical techniques to study the status, sustainable use, distribution, and trophic ecology of reptiles in the USA and Cameroon. 